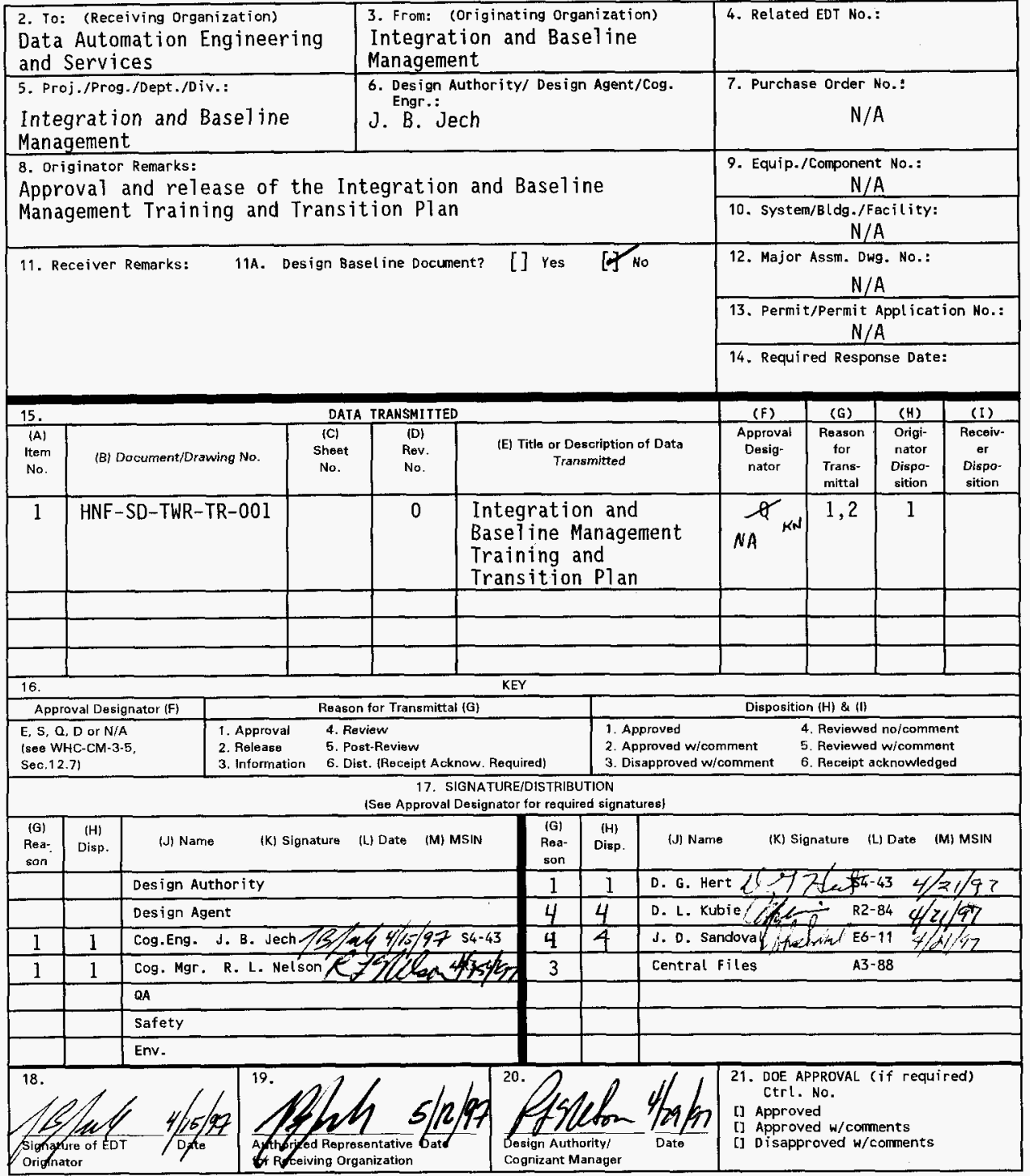

BD-7400-172-2(05/96) GEF097 


\section{Integration and Baseline Management Training and Transition Plan}

J. B. Jech

Lockheed Mart in Hanford Corporation, Richland, WA 99352

U.S. Department of Energy Contract DE-AC06-96RL13200

$\begin{array}{lll}\text { EDT/ECN: } & 618375 & \text { UC: } 605 \\ \text { Org Code: } & 77800 & \text { Charge Code: } N 1027 \\ \text { B\&R Code: } & \text { EW3120071 } & \text { Total Pages: } 16 \mathrm{kN}\end{array}$

Key Words: Master Equipment List, MEL, Training

Abstract: Integration and Baseline Management Training and Transition Plan.

TRADEMARK DISCLAIMER. Reference herein to any specific comercial product, process, or service by trade name, trademark, manufacturer, or otherwise, does not necessarily constitute or imply its endorsement, recommendation, or favoring by the United States Goverment or any agency thereof or its contractors or subcontractors.

Printed in the United States of America. To obtain copies of this document, contact: Document Control Services, P.0. Box 950, Mailstop H6-08, Richland WA 99352, Phone (509) 372-2420; Fax (509) 376-4989.
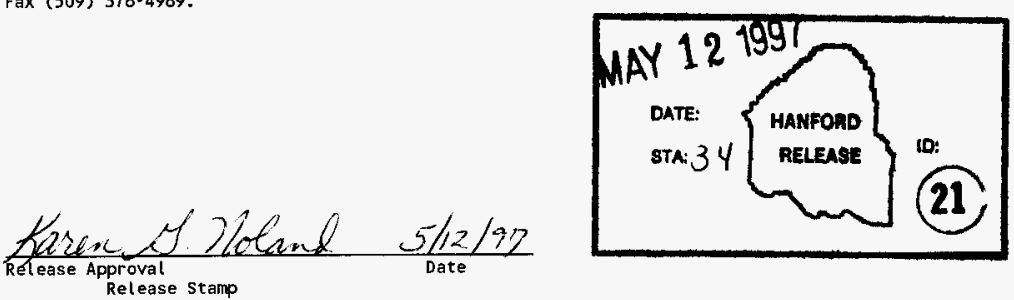

Approved for Public Release 
Unclassified

HNF-SD-TWR-TR-001, Rev. 0

Page 1

Integration and Baseline Management

TRAINING AND TRANSITION PLAN

April 1997

Prepared For:

Lockheed Martin Services

Prepared By

Fluor Daniel Northwest, Inc. 
$\underline{\text { Unclassified }}$

HNF-SD-TWR-TR-001, Rev. 0

Page 2

Integration and Baseline Management

TRAINING AND TRANSITION PLAN

Revision 0

TABLE OF CONTENTS

Section

Page Number

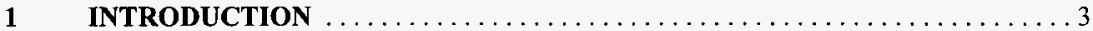

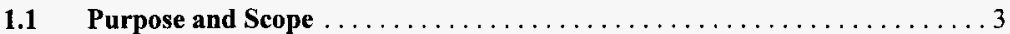

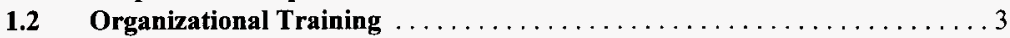

1.3 Facility and Process Descriptions $\ldots \ldots \ldots \ldots \ldots \ldots \ldots \ldots \ldots \ldots \ldots$

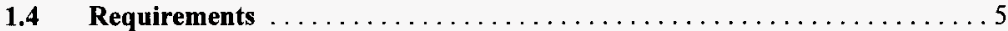

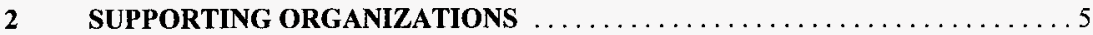

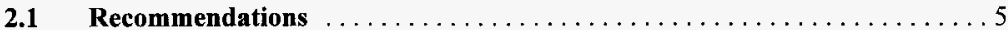

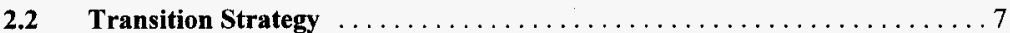

3 TRAINING OVERVIEW $\ldots \ldots \ldots \ldots \ldots \ldots \ldots \ldots \ldots \ldots \ldots \ldots \ldots \ldots \ldots$

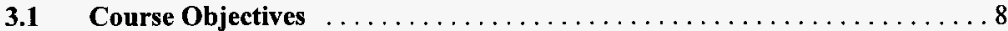

3.1.1 Master Equipment List - General Overview $\ldots \ldots \ldots \ldots \ldots \ldots \ldots 8$

3.1.2 Master Equipment List - Editing $\ldots \ldots \ldots \ldots \ldots \ldots \ldots \ldots$

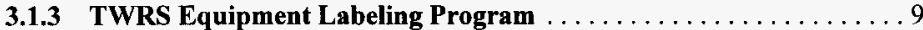

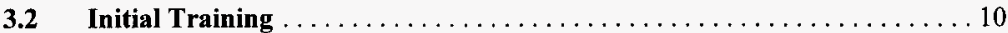

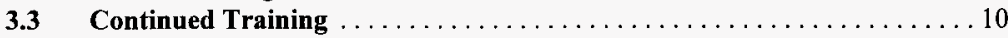

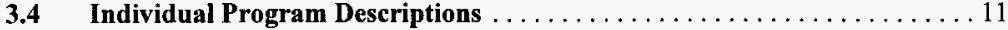

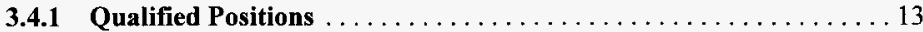

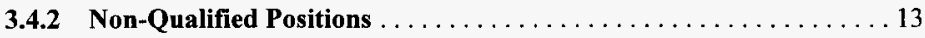

4 QUALIFICATION PROGRAM PLANNING AND ADMINISTRATION . . . . 13

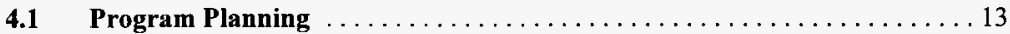

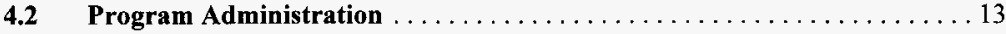

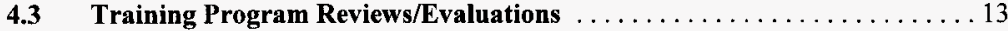

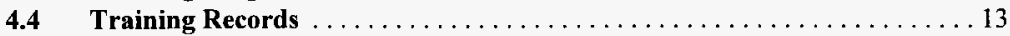

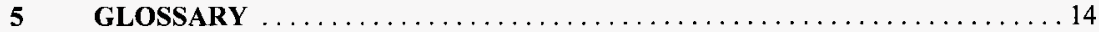

6 REFERENCE DOCUMENTS $\ldots \ldots \ldots \ldots \ldots \ldots \ldots \ldots \ldots \ldots \ldots \ldots$ 
Unclassified

HNF-SD-TWR-TR-001, Rev. 0

Page 3

\section{INTRODUCTION}

\subsection{Purpose and Scope}

The purpose of the Integration \& Baseline Management Training and Transition Plan is to provide a training outline for the Integration \& Baseline Management (I\&BM) organization and a transition strategy for the Master Equipment List (MEL) Phase I application. The training outline includes the following courses:

\section{MEL Phase I Application}

Course 1 Master Equipment List - General Overview.

Course 2 Master Equipment List - Editing.

\section{Tank Waste Remediation System (TWRS) Labeling Related.}

Course 3 TWRS Equipment Labeling Program (Course No. 350545).

As part of courses 1,2, and 3, it is recommended that a lesson plan be developed and integrated into each of the three courses on the subject of Configuration Management (CM) to include: $\mathrm{CM}$ concepts, terminology, definitions, fundamentals and its application with respect to the course.

The strategy for the MEL Phase I application is to train internal organizations (I\&BM) on the MEL-General Overview for read only users and train MEL-Editing for edit users (only on an as needed basis). For external organizations, the strategy is to train selected personnel on the MEL-General Overview and transition them from read only privileges to editing privileges when the appropriate administrative procedures that outline the external organization's responsibilities (to support MEL) are established.

The purpose of this training is to ensure support of the I\&BM organization objectives within the TWRS Division. These training courses will be added to the existing required training for I\&BM personnel only. Other organizations implementing the training will be directed by their management on which training is required.

\section{$1.2 \quad$ Organizational Training}

The organizations that will be implementing or receiving this plan's training, per their management, are those within the TWRS Division. The organizations that work directly with the MEL Phase I application information (inputting, editing, reviewing, and approving MEL data) 
and assist in implementing the TWRS Equipment Labeling program are likely candidates for training.

At this time, only the TWRS Equipment Labeling Program (Course No. 350545) training has been implemented. Both the MEL-General Overview and the MEL-Editing course materials have been developed and training has been conducted informally to the I\&BM organization by the TWRS Training organization and other organizational support personnel.

Certain job positions will require a qualification (obtain a qualification card) in the MEL-Editing, and as with any qualification, it is the responsibility of management to ensure that the qualification training is up to date. Only the MEL-Editing course requires a qualification. The MEL-Editing is not part of and does not impact the overall qualified position training criteria (i.e., to be qualified to become a Cognizant Engineer). The MEL-Editing qualification is an internal criteria and is a requirement to input, edit, review, and approve MEL data.

The organizations affected are also required to read the IP-0842 procedures that may accompany any of the training per the TWRS Training organization.

\subsection{Facility and Process Descriptions}

The facilities that require this training are the Tank Farms located in the 200 Area at the Hanford Site under the responsibility of the Tank Waste Remediation System Division. Currently, tank farm workers that perform walkdowns in the Tank Farms are required by their job function to follow the training descriptions outlined in the TWRS Training Implementation Matrix per DOE Order 5480.20A, "Personnel Selection, Qualification, and Training Requirements at DOE Nuclear Facilities".

This plan supports the TWRS Administration Manual, WHC-IP-0842, Vol. III, Training. This plan is also intended to support the training necessary to perform the processes defined in the TWRS Administration Manual Vol. IV, Section 4.14. This entire process addresses labeling tank farm equipment, drawing generation, and the use of the Master Equipment List Phase I application.

The criteria set forth in this plan will follow the facility training requirements as defined in the TWRS Training Implementation Matrix which discusses the individual qualification program description requirements. 
Unclassified

HNF-SD-TWR-TR-001, Rev. 0

Page 5

\subsection{Requirements}

The DOE Order 5480.20A, "Personnel Selection, Qualification, and Training Requirements at DOE Nuclear Facilities", describes the application of the selection, qualification, certification, and training requirements. These requirement criteria determine what Facility Organizations and which Qualified Positions require various training.

The DOE Order 5480.19, "Conduct of Operations", requires the establishment of a program to control configuration changes that ensure equipment and system status (including labeling) is maintained. The recommended configuration management training mentioned in this plan, once developed, should satisfy this DOE Order.

The DOE Standard, Guide for Operational Configuration Management Program, DOE-STD-1073-93, outlines a program criteria and implementation guidance for an operational CM program for DOE facilities. This standard is applicable to DOE nuclear facilities in the operational phase and has been specified in the TWRS Standards/Requirements Identification Document as a source requirement. Therefore, the $\mathrm{CM}$ training will be integrated into the three courses. The CM training will include: $\mathrm{CM}$ concepts, terminology, definitions, fundamentals and its application with respect to the course. Configuration Management is recognized as an important element for a well-rounded training program to support the I\&BM organization.

\section{SUPPORTING ORGANIZATIONS}

Several organizations are involved with supporting the I\&BM organization and will share the responsibility of selected tasks associated with the MEL Phase I application. A Responsibility Matrix, to be included in the MEL Implementation Plan, has been proposed for implementation and will define these supporting organizations with the I\&BM organization. Once implemented, this matrix will identify those organizations that will participate in the data collection of specific fields for the MEL Phase I application. These organizations supporting MEL, from the viewpoint of collecting data and populating MEL, will be recognized as data owners of MEL in a separate Data Management Plan.

The key supporting organization is Tank Farm Operations and their support staff. The program descriptions of the support staff are outlined in Section 3.4, Individual Program Descriptions.

\subsection{Recommendations}

The recommendations for each of the follow training are based on the present status of the course: 
Unclassified

1. MEL Phase I application training recommendation for MEL-General Overview and MEL-Editing:

a. Internal training (internal to I\&BM) will be conducted after an established data set, for training purposes, has been populated in MEL. This training shall include the MEL-General Overview. The MEL-Editing training will be given only to those selected personnel whose job functions require it, as determined by I\&BM management.

b. External training (outside of I\&BM's organization) for the MEL-General Overview training will also be given to those requiring immediate training.

c. External training for the MEL-Editing will not be given until after the WHC-IP-0842 administrative procedures are complete so that the external organization's responsibilities (from a data management standpoint) can be communicated in the training and reinforced with a released procedure. These procedures can be written once the data ownership roles and responsibilities are established and business processes have been defined.

The MEL-Editing will require a qualification. This training will qualify those personnel to input, edit, review, and approve MEL data. Since the MEL Phase I application is a qualified database, personnel need to be trained on how these functions operate in the application.

In summary, recognizing the need for immediate MEL-General Overview training, the participant text course materials are complete and the TWRS Training Organization and other organizational support personnel are prepared to give this training.

2. TWRS Equipment Labeling Program (Course No. 350545) training recommendation:

a. Both internal and external training will be conducted as needed. The training has been conducted and shall continue to be implemented to the appropriate organizations and disciplines as required by management. The participant text course materials are complete and the TWRS Training Organization is prepared to support this training.

This training is targeted towards personnel performing maintenance, operations, engineering, and activities that are associated with: locating, identifying, surveillance, monitoring, and/or data collection involving structures, systems, and components within the Tank Farm facility.

3. Configuration management training recommendation: 
Unclassified

a. Develop CM concepts, terminology, definitions, fundamentals and its application with respect to the course and integrate the $\mathrm{CM}$ training in the following courses:

MEL-General Overview, MEL-Editing, and the TWRS Equipment Labeling Program.

Both internal and external $\mathrm{CM}$ training will be conducted as needed. The $\mathrm{CM}$ training has not been conducted and it is recommended that this training be implemented to the appropriate organizations and disciplines as required. The participant text course materials are not complete, but the TWRS Training Organization is prepared to support rapid development. This training will be targeted towards personnel performing tasks that require audit ability and traceability.

At this time, the TWRS Administration, Vol. IV, Section 4.14, has an approved procedure to support the I\&BM organization (required reading to I\&BM personnel).

\subsection{Transition Strategy}

The strategy of the MEL Phase I application training is to train the internal I\&BM organization to: 1) MEL-General Overview for read only users; and 2) MEL-Editing for edit users (only on an as needed basis). For external organizations, the strategy is to train the MEL-General Overview, but limit to those requiring immediate training as determined by management.

Once a farm is labeled and drawings and documents are released, a time period to migrate the label data from the existing Paradox database system to the MEL Phase 1 application will occur to populate the MEL Phase I application. When the MEL Phase I application is populated and in a state that external organization can view data, then they will be allowed read only privileges to MEL. Prior to this data migration, the external organization's selected personnel will need to receive training for the MEL-General Overview. For external organizations, the transition from read only privileges to editing privileges will not occur until the appropriate administrative procedures that outline the external organization's responsibilities (to support MEL) are established. Until then, the MEL-Editing training will not be implemented.

The strategy of the TWRS Equipment Labeling Program is to continue to train personnel per management requirements.

The strategy to support the CM training is to have the TWRS Training development team define a CM lesson plan to include: CM concepts, terminology, definitions, fundamentals and its application with respect to the course and integrate the $\mathrm{CM}$ training in the following courses: MEL-General Overview, MEL-Editing, and the TWRS Equipment Labeling Program. Once the $\mathrm{CM}$ lesson plan is complete ensure that the appropriate personnel review it. 
$\underline{\text { Unclassified }}$

HNF-SD-TWR-TR-001, Rev. 0

Page 8

\section{TRAINING OVERVIEW}

\subsection{Course Objectives}

The I\&BM courses consist of: MEL-General Overview; MEL-Editing; and the TWRS Equipment Labeling Program. CM training will be integrated within each of these courses and communicated how CM applies with respect to the course.

The course objectives follow.

\subsubsection{Master Equipment List - General Overview}

This course covers the two basic elements of the MEL Phase I application that include: 1) the fundamentals and applicability of $\mathrm{CM}$ to the training and 2) general navigation and functions of MEL. Previous training was conducted informally during MEL's software release version 1.34.

This training shall be a four-hour, initial training session. The environment of the class will be 'hands on' with computers available for performing exercises after the instructor has reviewed the materials with users.

Due to immediate needs of the 'hands-on' training, the CM portion will be delayed until the lesson plan has been developed.

The objectives of this course are to:

Part 1: a) Discuss CM concepts, terminology, definitions, fundamentals and its application with respect to the course.

Part 2: a) Discuss how to install the MEL Phase I application.

b) Understand how to launch the MEL Phase I application and the log on.

c) Understand how to use the menu, toolbar, and hints.

d) Understand how to move through the application to view data.

e) Understand how to use Find and Find Next.

f) Understand how to use Queries.

g) Understand how to print Reports.

h) Understand Changes Pending. 
Unclassified

HNF-SD-TWR-TR-001, Rev. 0

Page 9

\subsubsection{Master Equipment List - Editing}

This course covers the three basic elements of the MEL Phase I application that include: 1) the fundamentals and applicability of $\mathrm{CM}$ to the training and; 2) general navigation and functions of MEL; and 3) editing functions in MEL. Previous training was conducted informally during MEL's software release version 1.34.

This training shall be an eight-hour, initial training session to support a qualification. Each part of the course will include in-class exercises. The environment of the class will be 'hands on' with computers available for performing exercises after the instructor has reviewed the material. Due to immediate needs of the 'hands-on' training, the CM portion will be delayed until the lesson plan has been developed.

The objectives of this course are to:

Part 1: a) Discuss CM concepts, terminology, definitions, fundamentals and its application with respect to the course.

Part 2: a) Discuss how to install the MEL Phase I application.

b) Understand how to launch the MEL Phase I application and the log on.

c) Understand how to use the menu, toolbar, and hints.

d) Understand how to move through the application to view data.

e) Understand how to use Find and Find Next.

f) Understand how to use Queries.

g) Understand how to print Reports.

h) Understand Changes Pending.

Part 3: a) Understand how to perform an Edit session.

b) Understand each of the functions on the MEL Edit Menu.

c) Understand how to view or edit from Pending Changes.

d) Understand how to Post and Cancel.

e) How to view posted changes in Change Log.

f) Discuss Data Standardization and Data Management.

\subsubsection{TWRS Equipment Labeling Program}

This course covers the basic elements of the TWRS Equipment Labeling Program that include: 1) the fundamentals and applicability of CM to the training and;2) basics of how equipment and systems are labeled in the tank farms and the purpose of the labeling program. 
Unclassified

Due to immediate needs of the 'hands-on' training, the CM portion will be delayed until the lesson plan has been developed.

The objectives of this course are to:

Part 1: a) Discuss CM concepts, terminology, definitions, fundamentals and its application with respect to the course.

Part 2: a) Discuss the requirements for labeling in Tank Farms.

b) Understand how to identify the Tank Farm label format and information fields.

c) Understand how to interpret equipment data on the label.

d) Understand organizational responsibilities associated with the Labeling Program.

e) Understand the labeling approval process.

f) Understand the purpose of the H-14 drawings and identify drawing formats, references.

g) Understand how to interpret drawing symbols and represented equipment.

h) How to identify associated $\mathrm{H}-14$ drawings.

i) Describe the process for changing labels.

j) Discuss the label data requirements associated with Lockout/Tagouts.

k) Discuss the process of transition to the new labeling and drawing system.

l) Discuss the Master Equipment List access.

\subsection{Initial Training}

Initial training is necessary for the MEL-Editing and the TWRS Equipment Labeling Program. The MEL-General Overview, however, is recommended initial training and does not need to be refreshed annually unless significant version changes are made in the MEL Phase I application, software release versions.

Per WHC-CM-2-15, Training Standards, the 'initial training' is defined as:

The first training activity or course in an ongoing series of continuing training events. Initial training introduces the student to the subject matter and serves as the entry point into the training cycle.

\subsection{Continued Training}

The continued training is necessary for 1) the TWRS Equipment Labeling Program (Course No. 350545) as procedures are revised and 2) the Master Equipment List-Editing as software version changes are made in MEL Phase I application that could impact the editing functions. Per the TWRS Training Implementation Matrix, continued training programs are established for 
Unclassified

operating organization personnel who perform functions associated with engineered safety features.

\subsection{Individual Program Descriptions}

In accordance with the TWRS Training Implementation Matrix per DOE Order 5480.20A, there are no positions which require certification. TWRS personnel do not handle significant quantities of fissionable material. Terminology in the existing Union Contract refers to operator "certification". This is considered equivalent to "qualification" as defined in DOE 5480.20A. The positions listed below are noted if they are qualified positions at TWRS. The method used to qualify personnel is described in detail in WHC-IP-0842, Volume III, Section 10, "TWRS Training Program Descriptions".

In Table 1.0, Training Matrix, if the individual program description has been recognized as a qualified program affected by the MEL Phase I application training, then it is in the "Position" column. The MEL-Editing course is the qualification requirement and is noted as such.

As mentioned earlier, the qualification requirement is based on the organizations that are responsible for inputting, editing, reviewing, and approving MEL data. These organization's personnel are likely candidates to receive training outlined in this plan, but only their management can determine if the training is required. The MEL-Editing qualification is an internal criteria and is a requirement to input, edit, review, and approve MEL data.

Per WHC-CM-2-15, Training Standards, a qualification requirement is defined as "a set of knowledge or skills needed to do all activities in a job, occupation, or profession." If any of the three training courses met this criteria (for an individual program) then it was determined that the person should be qualified in that specific training.

This plan shall also follow the requalification guidelines that are outlined in WHC-CM-2-15, Training Standards. 
Unclassified

\section{TABLE 1.0 TRAINING MATRIX}

\begin{tabular}{|l|l|l|l|}
\hline Position & $\begin{array}{l}\text { Course 1: } \\
\text { MEL - General } \\
\text { Overview }\end{array}$ & $\begin{array}{l}\text { Course 2: } \\
\text { MEL - Editing } \\
\text { (Qualification Is Required) }\end{array}$ & $\begin{array}{l}\text { Course 3: } \\
\text { Equipment \& } \\
\text { System } \\
\text { Labeling }\end{array}$ \\
\hline Cognizant Engineer & Initial & Initial, Continued & Initial \\
\hline Data Entry & Initial & Initial, Continued & Initial \\
\hline Design Authority & Initial & Initial, Continued & Initial \\
\hline $\begin{array}{l}\text { Facility Environment } \\
\text { Professional }\end{array}$ & Initial & N/A & Initial \\
\hline $\begin{array}{l}\text { Operations/ } \\
\text { Maintenance Mgr. }\end{array}$ & Initial & N/A & Initial \\
\hline NPO Supervisor & Initial & N/A & Initial \\
\hline $\begin{array}{l}\text { Ops. Eng./Shift Ops. } \\
\text { Mgr. }\end{array}$ & Initial & Initial*, Continued & Initial \\
\hline Persons In Charge & Initial & N/A & Initial \\
\hline Planners & Initial & Initial*, Continued & Initial \\
\hline $\begin{array}{l}\text { Quality Assurance } \\
\text { (QA) Engineer }\end{array}$ & Initial & N/A & Initial \\
\hline Safety Professional & Initial & N/A & Initial \\
\hline
\end{tabular}

* May require Initial and Continued training--To Be Determined. 
$\underline{\text { Unclassified }}$

HNF-SD-TWR-TR-001, Rev. 0

Page 13

\subsubsection{Qualified Positions}

The Cognizant Engineer, Design Authority, Facility Environmental Professional, Operations/Maintenance Manager, Nuclear Process Operator Supervisors, Operations Engineer/ Shift Operations Manager, Quality Assurance Engineers, Safety Professional programs have all been designated as requiring qualification in accordance with DOE Order $5480.20 \mathrm{~A}$. Only those qualified positions that require a qualification for MEL-Editing are in Table 1.0, Training Matrix.

\subsubsection{Non-Qualified Positions}

The Data Entry, Persons-In-Charge, and Planner programs have not been designated as a qualification in accordance with DOE Order 5480.20A. Only those non-qualified positions that require a qualification for MEL-Editing are in Table 1.0, Training Matrix.

\section{QUALIFICATION PROGRAM PLANNING AND ADMINISTRATION}

\subsection{Program Planning}

The Integration \& Baseline Management is the organization that will be responsible for coordinating with TWRS Training to set up the training sessions for I\&BM, informing TWRS Training on updates to course materials, lesson plans, and in assisting in identifying the organizations that need to be attending the training.

\subsection{Program Administration}

The organization that will be administering this formal training is the TWRS Training organization. This organization is responsible for the initial training and refresher training and all training aspects outlined in the TWRS Administration Manual, WHC-IP-0842, Vol. III.

\subsection{Training Program Reviews/Evaluations}

After each training course, program reviews and evaluations will be conducted for each of the class participants upon completion. The purpose is to identify strengths and weaknesses in the training and target areas for improvement.

\subsection{Training Records}

Qualification records are maintained in accordance with WHC-IP-0842, Vol. III, Section 3.0, "TWRS Training Records Management". 
Unclassified

\section{GLOSSARY}

course

A unit of training consisting of one or more lesson plans of structured, sequential steps.

\section{development}

(1) The second phase of performance based training, the phase that uses information collected during the analysis phase to select training settings, establish a training program development plan, write specific learning objectives, and test specifications that guide the development of all training materials and strategies. (2) To create, plan, sketch, or outline; to construct a lesson plan with an approved format; a method for making or doing.

\section{formal training}

A formal presentation of detailed information, using classroom, laboratory, or simulation devices, in which objectives learned can be measured. Formal training complies with DOE order, federal or state regulations, or management direction and is presented by a qualified instructor using an approved lesson plan.

\section{initial training}

The first training activity or course in an ongoing series of continuing training events. Initial training introduces the student to the subject matter and serves as the entry point into the training cycle.

\section{informal training}

Training without formality and documentation; e.g., OUT without formality, on-the-job experience, watching experienced workers, using procedures and job aids, unintentional training.

\section{objective}

A clear concise statement of measurable actions or skills or an attitude or body of knowledge, with their conditions and standards that a learning experience should teach participants.

\section{qualification}

The satisfactory completion of a training program based on knowledge, skills, and abilities needed to do assigned responsibilities.

\section{qualification requirements}

A set of knowledge or skills needed to do all activities in a job, occupation, or profession. 
Unclassified

\section{qualified}

The training status achieved by an individual who masters the required knowledge and skills to do a task or job successfully.

\section{REFERENCE DOCUMENTS}

Configuration Management Plan, HNF-SD-GN-CM-501, Rev. C, Fluor Daniel Northwest, Richland, Washington, 1996.

Conduct of Operations Per DOE Order 5480.19,

Westinghouse Hanford Company, Richland, Washington, 1996.

Guide for Operational Configuration Management Program, DOE-STD-1073-93, Rev. 0, Fluor Daniel Northwest, Richland, Washington, 1997.

Training Implementation Matrix Per DOE Order 5480.20A, Rev. 0, Westinghouse Hanford Company, Richland, Washington, 1996.

Training Standards, WHC-CM-2-15, Rev. 0,

Westinghouse Hanford Company, Richland, Washington, 1995.

TWRS Equipment Labeling Program, Course Number 350545, Rev. O, Westinghouse Hanford Company, Richland, Washington, 1996.

Waste Tanks Administration, WHC-IP-0842, Volumes III and IV, Westinghouse Hanford Company, Richland, Washington, 1997. 